\title{
Growth Hormone and ACTH Deficiency in a Diabetic Adult
}

\author{
Asif Ali Memon, Mehwish Gilani, Naveed Asif and Nida Basharat
}

\begin{abstract}
Adult growth hormone deficiency (AGHD) syndrome has a constellation of features, like impaired cognitive function, altered body composition, poor quality of life and various metabolic changes. Most of its features resemble signs of aging as growth hormone $(\mathrm{GH})$ secretion decreases with age. Hypothalamic-pituitary-adrenal (HPA) axis should be thoroughly investigated in this disease as patients with $A G H D$ are at risk of life-threatening consequences due to partial or complete ACTH deficiency, especially in stressful conditions. GH deficiency has also been related to diabetes or glucose intolerance. It is relatively underdiagnosed problem in adults and requires a thorough workup including dynamic function tests like insulin tolerance test (ITT), which has been termed as the gold standard for the diagnosis of patients with ACTH deficiency.
\end{abstract}

Key Words: Adult growth hormone deficiency, Adrenal insufficiency, Diabetes mellitus, Insulin tolerance test.

\section{INTRODUCTION}

The anabolic growth hormone is synthesised by the somatotrophs cells of the anterior pituitary gland. It mediates its biological actions by binding to the extracellular domain of the $\mathrm{GH}$ receptor. Its secretion is regulated by the hypothalamus. Factors regulating its secretion are: growth hormone releasing hormone $(\mathrm{GHRH}), \mathrm{GH}$ releasing peptide (ghrelin), somatostatin and IGF-1. Disorder of growth hormone are either due to its hypersecretion or deficiency. ${ }^{1}$

Adult growth hormone deficiency (AGHD) is a syndrome which is characterised by decrease in bone mass, poor memory and cognitive function, changes in body mass composition, i.e. decrease lean body mass and increased total fat mass, diminished cardiac function, diminished activity of aerobic exercise capacity, diminished quality of life, adverse carbohydrate, lipid metabolic changes, and high rates of cardiovascular risk factors. ${ }^{2} \mathrm{GH}$ secretion decreases with age, that is why some of its manifestations of pathological GH deficiency mimic the clinical features of normal aging. ${ }^{3}$

$\mathrm{GH}$ deficient patients are at increased risk of developing subtle to complete ACTH deficiency; thus putting them at increased risk of developing life-threatening consequences in periods of stress. Therefore, the HPA should be appropriately investigated in these patients. The spectrum of hypoadrenalism ranges from the full blown adrenal crisis to subtle dysfunctions in asymptomatic patients. ${ }^{4}$

Department of Chemical Pathology and Endocrinology, Armed Forces Institute of Pathology (AFIP), Rawalpindi, Pakistan

Correspondence: Dr. Asif Ali Memon, Department of Chemical Pathology and Endocrinology, Armed Forces Institute of

Pathology (AFIP), Rawalpindi, Pakistan

E-mail: asifpath9@gmail.com

Received: February 08, 2018; Accepted: November 23, 2018

\section{CASE REPORT}

A 51-year male, known case of type-2 diabetes mellitus for the last 12 years, came to Endocrine Clinic, Department of Chemical Pathology and Endocrinology, Armed Forces Institute of Pathology, Rawalpindi in November 2017 for the evaluation of growth hormone deficiency and ACTH deficiency. The patient was complaining of having a poor memory, being unable to concentrate, a low mood, easy fatigability and laziness since one year. $\mathrm{He}$ also complained of staying in social isolation most of the times. He was on antidiabetics for the last 12 years.

At the time of presentation, he was a depressed looking man with a medium built, well oriented in time, place and person. On general physical examination, he had a pulse of 76 beats per min, blood pressure was 130/80 $\mathrm{mm}$ of $\mathrm{Hg}$, and respiratory rate was 16 breaths per minute. His height was $168 \mathrm{~cm}$ and he weighed $65.4 \mathrm{Kgs}$ with a body mass index of $23.17 \mathrm{Kg} / \mathrm{m}^{2}$. Systemic examinations of cardiovascular system, gastrointestinal system, respiratory system and central nervous system were unremarkable. The patient was married and had four children.

His routine laboratory investigations showed a hemoglobin of $15.1 \mathrm{~g} / \mathrm{dl}$ (normal range for age 13-17 g/dL), total leucocyte count of $6.7 \times 10^{9} / \mathrm{L}$ (normal range $4-10$ $\times 10^{9} / \mathrm{L}$ ), platelet count of $157 \times 10^{9} / \mathrm{L}$ (normal range $\left.150-400 \times 10^{9} / \mathrm{L}\right)$. He had a normal renal and liver function profile. His bone profile showed a normal serum calcium, phosphorous, vitamin $D$ and alkaline phosphatase levels. His lipid profile showed a total cholesterol level of $3.90 \mathrm{mmol} / \mathrm{L}$ (normal range for age, $<5.2 \mathrm{mmol} / \mathrm{L}$ ), normal low-density lipoprotein (LDL)cholesterol level of $2.32 \mathrm{mmol} / \mathrm{L}$ (normal range for age, $<2.59 \mathrm{mmol} / \mathrm{L}$ ), triglyceride of $0.84 \mathrm{mmol} / \mathrm{L}$ (normal range $<1.6 \mathrm{mmol} / \mathrm{L}$ ), and high-density lipoprotein (HDL)cholesterol level of $1.20 \mathrm{mmol} / \mathrm{L}$ (normal range $>1.04$ $\mathrm{mmol} / \mathrm{L}$ ). His diabetic profile showed a fasting glucose concentration of $6.6 \mathrm{mmol} / \mathrm{L}$ (normal range $<7.0 \mathrm{mmol} / \mathrm{L}$ ) and a glycosylated hemoglobin concentration of $5.7 \%$ 
(normal range $<6.5 \%$ ). His serum ferritin was $57.1 \mathrm{ng} / \mathrm{ml}$ (normal range $24-336 \mathrm{ng} / \mathrm{ml}$ ). His urine routine examination was also normal.

The patient underwent various endocrinological investigations which included a normal thyroid stimulating hormone level of $1.06 \mathrm{mIU} / \mathrm{L}$ (normal range 0.4-4.5 $\mathrm{mIU} / \mathrm{L})$, serum luteinizing hormone $(\mathrm{LH}) 3.8 \mathrm{mlU} / \mathrm{ml}$ (normal range 1.2-8.6 $\mathrm{mlU} / \mathrm{ml}$ ), follicle stimulating hormone $(\mathrm{FSH})$ concentration of $4.0 \mathrm{mlU} / \mathrm{L}$ (1.3-19.3 $\mathrm{mlU} / \mathrm{ml}$ ), testosterone levels were $13.1 \mathrm{nmol} / \mathrm{L}$ (normal range $6-27 \mathrm{nmol} / \mathrm{L}$ ) and serum prolactin was $117 \mathrm{mIU} / \mathrm{L}$ (normal range 40-360 $\mathrm{mIU} / \mathrm{L}$ ). He had a normal concentration of various trace metals that included zinc, copper, lead and arsenic.

Before starting the dynamic endocrinological investigations, he was given the adult growth hormone deficiency quality of life assessment proforma, which is a conditionspecific quality of life measure for use in clinical trials and for the routine monitoring of patients, ${ }^{5}$ to fill up by himself to assess his quality of life (Table I). The score of this patient was 14 out of 25 .

Dynamic endocrine investigations done at AFIP showed inadequate growth hormone $(\mathrm{GH})$ response to Levodopa stimulation $(\mathrm{GH},<0.15 \mathrm{mlU} / \mathrm{L}$ [normal response, $>15$ $\mathrm{mIU} / \mathrm{L}]$; and post-insulin tolerance test $(\mathrm{GH},<0.15 \mathrm{mlU} / \mathrm{L}$ [normal response, $>20 \mathrm{mlU} / \mathrm{L}]$. He also showed an inadequate cortisol response to insulin-induced hypoglycemia (basal cortisol $=221 \mathrm{nmol} / \mathrm{L}$, post 30 minutes stimulation $=238 \mathrm{nmol} / \mathrm{L}$ and post 60 min stimulation $=$ $303 \mathrm{nmol} / \mathrm{L}$ ) consistent with the diagnosis GHD and

Table I: The proforma used for measuring the quality of life.

\begin{tabular}{l|c|c}
\hline Parameters & Yes & No \\
\hline I have struggle to finish job & $\checkmark$ & \\
\hline I feel a strong need to sleep during the day & & $\checkmark$ \\
\hline I often feel lonely when I am with other people & $\checkmark$ & \\
\hline I have to read things several times before they sink in & & $\checkmark$ \\
\hline It is difficult for me to make friends & $\checkmark$ & \\
\hline It takes a lot of effort for me to do simple tasks & & $\checkmark$ \\
\hline I have difficulty controlling my emotions & $\checkmark$ & \\
\hline I often lose my track of what I want to say & & $\checkmark$ \\
\hline I lack confidence & $\checkmark$ & \\
\hline I have to push myself to do things & & $\checkmark$ \\
\hline I often feel very tense & $\checkmark$ & \\
\hline I feel as if I let people down & & $\checkmark$ \\
\hline I find it hard to mix with people & $\checkmark$ & \\
\hline I feel worn out even when I have not done any thing & $\checkmark$ & \\
\hline There are times when I feel very low & $\checkmark$ & \\
\hline I avoid responsibility & & $\checkmark$ \\
\hline If possible, I avoid mixing with people whom I do not know very well & $\checkmark$ & $\checkmark$ \\
\hline I feel as if I am a burden to people & & \\
\hline I often forget what people have said to me & & $\checkmark$ \\
\hline I find it difficult to plan ahead & & \\
\hline I often feel too tired to do things I ought to do & & $\checkmark$ \\
\hline
\end{tabular}

adrenocortical insufficiency. He had a low plasma adrenocorticotrophic hormone (ACTH) concen-tration of $18.7 \mathrm{pg} / \mathrm{ml}$ (normal range $10-85 \mathrm{pg} / \mathrm{ml}$ ) $\mu \mathrm{g} / \mathrm{dL}$. IGF-I and IGFBP-3 were $25 \mathrm{nmol} / \mathrm{L}$ (normal range for age 11.5$30.5 \mathrm{nmol} / \mathrm{L}$ ) and $229 \mathrm{nmol} / \mathrm{L}$ (normal range for age, 142$205 \mathrm{nmol} / \mathrm{L}$ ), respectively. MRI brain showed a $9 \times 4 \times 6$ $\mathrm{mm}$ cystic are in pituitary gland representing a partially empty sella.

Patient was referred to medical unit for start of treatment which consisted of maintaining IGF-1 concentration within reference range by starting growth hormone therapy. Patient was advised to get his IGF-1 levels checked after two months of start of therapy.

\section{DISCUSSION}

Loss of the physiological effects of growth hormone results in malfunctioning of various organ systems, ${ }^{6}$ which are manifested by a number of metabolic, muscular, cardiac, neuropsychiatric, cognitive performance and bone symptom. ${ }^{7}$ Unfortunately, there is no single parameter which offers a reliable diagnostic usefulness in a suspected case of $\mathrm{GH}$ deficient patient. 8

This patient had typical neuropsychiatric symptoms of $\mathrm{GH}$ deficiency, like depression, lethargy, laziness, impaired cognitive functions, difficulty in concentrating and finishing tasks. Quality of life assessment proforma, duly filled by the patient, clearly indicated a low quality of life with factors which were hampering his daily activities, and were quite disturbing for him.

GHD is complex disease with constellation of signs and symptoms involving metabolism at various levels. As $\mathrm{GH}$ shares the same signalling molecule as insulin which can be a reason for its insulin mimetic action. Therefore, deficiency of $\mathrm{GH}$ can be linked to the development of glucose intolerance or diabetes, like in this patient. ${ }^{9}$ This patient had a QoL-AGHD score of 14 which correlates with those documented by Häggström et al. ${ }^{10}$

A number of isolated growth hormone deficient patients can have anterior pituitary hormone deficits. They are at increased risk of developing partial or complete ACTH deficiency as reported in this patient. These patients can have potentially life-threatening consequences due of inappropriate hypothalamic-pituitary-adrenal axis (HPA) response to stressful stimuli. Therefore, it is very essential to evaluate the integrity of the HPA in patients with GHD.7 ITT has been accepted as the gold standard for detection of sub-clinical or partial ACTH deficiency. It has been studied against the response to surgical stress and has been regarded as the reference method to evaluate the HPA axis. A cortisol response of 500-550 $\mathrm{nmol} / \mathrm{L}$ to insulin reflects normal functioning of HPA.

GHD is relatively a common problem in adults, but not been suspected commonly. The diagnosis of combined pituitary hormone deficiency requires dynamic function 
tests including insulin tolerance test and ghrelin stimulation test, which are not widely available in Pakistan except only at some tertiary care diagnostic centres. GHD has significant metabolic morbidities in adults. It is recognised as a syndrome with multiple organ involvement. GHD patients with ACTH deficiency should be alerted of the potential risk of adrenal insufficiency in stressful events.

\section{REFERENCES}

1. Ayuk J, Sheppard MC. Growth hormone and its disorders. Postgrad Med J 2006; 82:24-30.

2. Hazem A, Elamin MB, Bancos I, Malaga G, Prutsky G, Domecq JP, et al. Body composition and quality of life in adults treated with GH therapy: A systematic review and meta-analysis. Eur $J$ Endocrinol 2012; 166:13-20.

3. Kokshoorn NE, Biermasz NR, Roelfsema F, Smit JW, Pereira AM, Romijn JA. GH replacement therapy in elderly $\mathrm{GH}$-deficient patients: A systematic review. Eur J Endocrinol 2011; 164:657-65.

4. Maghnie M, Uga E, Temporini F, Di lorgi N, Secco A, Tinelli C, et al. Evaluation of adrenal function in patients with growth hormone deficiency and hypothalamic-pituitary disorders: Comparison between insulin-induced hypoglycemia, low-dose $\mathrm{ACTH}$, standard ACTH and $\mathrm{CRH}$ stimulation tests. Eur $\mathrm{J}$ Endocrinol 2005; 152:735-41.
5. Reed ML, Merriam GR, Kargi AY. Adult growth hormone deficiency - benefits, side effects, and risks of growth hormone replacement. Front Endocrinol (Lausanne) 2013; 4:64.

6. Braverman ER, Bowirrat A, Damle UJ, Yeldandi S, Chen TJ, Madigan $\mathrm{M}$, et al. Adult growth hormone deficiency treatment with a combination of growth hormone and insulin-like growth factor-1 resulting in elevated sustainable insulin-like growth factor-1 and insulin-like growth factor binding protein 3 plasma levels: A case report. J Med Case Rep 2010; 4:305.

7. Molitch ME, Clemmons DR, Malozowski S, Merriam GR, Vance ML. Evaluation and treatment of adult growth hormone deficiency: An endocrine society clinical practice guideline. J Clin Endocrinol Metab 2011; 96:1587-609.

8. Prodam F, Zavattaro M, Caputo M, Marzullo P, Aimaretti G. Diabetes in growth hormone deficiency. In diabetes secondary to endocrine and pancreatic disorders. Karger Publishers 2014; 22:10-21.

9. Koltowska-Haggstrom M, Hennessy S, Mattsson AF, Monson JP, Kind P. Quality of life assessment of growth hormone deficiency in adults (QoL-AGHDA): Comparison of normative reference data for the general population of England and Wales with results for adult hypopituitary patients with growth hormone deficiency. Horm Res 2005; 64:46-54.

10. Lange M, Feldt-Rasmussen U, Svendsen OL, Kastrup KW, Juul A, Müller J. High risk of adrenal insufficiency in adults previously treated for idiopathic childhood onset growth hormone deficiency. J Clin Endocrinol Metab 2003; 88:5784-9. 